\title{
Chemical Characterization of Fine Particulate Matter in Gasoline and Diesel Vehicle Exhaust
}

\author{
Hsi-Hsien Yang ${ }^{1,2}$, Narayan Babu Dhital ${ }^{1,2,3^{*}}$, Lin-Chi Wang ${ }^{4,5}$, Yueh-Shu Hsieh ${ }^{1}$, \\ Kuei-Ting Lee ${ }^{1}$, Ya-Tin Hsu ${ }^{1}$, Shi-Cheng Huang ${ }^{1}$ \\ ${ }^{1}$ Department of Environmental Engineering and Management, Chaoyang University of Technology, Taichung 41349, \\ Taiwan \\ ${ }^{2}$ Department of Applied Chemistry, Chaoyang University of Technology, Taichung 41349, Taiwan \\ ${ }^{3}$ Department of Environmental Science, Patan Multiple Campus, Tribhuvan University, Lalitpur, Nepal \\ ${ }^{4}$ Department of Civil Engineering and Geomatics, Cheng Shiu University, Kaohsiung 83347, Taiwan \\ ${ }^{5}$ Center for Environmental Toxin and Emerging-Contaminant Research, Cheng Shiu University, Kaohsiung 83347, Taiwan
}

\begin{abstract}
This study investigated the chemical composition (carbonaceous species, water-soluble ions and metal elements) of fine particulate matter $\left(\mathrm{PM}_{2.5}\right)$ emitted by gasoline and diesel vehicles. The emission factors of $\mathrm{PM}_{2.5}$, total hydrocarbons (THC), carbon monoxide (CO) and oxides of nitrogen $\left(\mathrm{NO}_{x}\right)$ were also determined. The emission measurements were performed for four gasoline and four diesel vehicles on a dynamometer with a constant volume sampling system. Vehicles having larger engines and higher accumulated mileages had higher emission factors of gaseous pollutants. Moreover, the average emission factor of $\mathrm{NO}_{x}$ was about 30 times higher for diesel vehicles than for gasoline vehicles. The average $\mathrm{PM}_{2.5}$ emission factors for gasoline and diesel vehicles were $1.57 \mathrm{mg} \mathrm{km}^{-1}$ and $57.8 \mathrm{mg} \mathrm{km}^{-1}$, respectively. The ratio of organic carbon to elemental carbon (OC/EC) was found to be a good indicator of gasoline vehicle emissions $(\mathrm{OC} / \mathrm{EC}>1)$ and diesel vehicle emissions $(\mathrm{OC} / \mathrm{EC}<1)$. Among water-soluble ions, $\mathrm{Ca}^{2+}$ and $\mathrm{SO}_{4}{ }^{2-}$ had the highest contribution to $\mathrm{PM}_{2.5}$ emitted by gasoline vehicles, while $\mathrm{NO}_{3}{ }^{-}, \mathrm{SO}_{4}{ }^{2-}$ and $\mathrm{Ca}^{2+}$ had the highest contribution to $\mathrm{PM}_{2.5}$ emitted by diesel vehicles. $\mathrm{Na}, \mathrm{Ca}, \mathrm{Fe}$ and $\mathrm{Zn}$ were the top four metal elements in terms of their contributions to $\mathrm{PM}_{2.5}$ mass for both types of the vehicles, while $\mathrm{Cd}, \mathrm{Cr}, \mathrm{Pb}$ and $\mathrm{Sb}$ were some of the toxic metal elements detected in $\mathrm{PM}_{2.5}$.
\end{abstract}

Keywords: Emission factor; Elemental carbon; Organic carbon; Water-soluble ion; Metal element.

\section{INTRODUCTION}

Road transportation can be an important contributor of atmospheric particulate matter (PM), carbon monoxide (CO), hydrocarbons $(\mathrm{HC})$, oxides of nitrogen $\left(\mathrm{NO}_{x}\right)$ and other toxic air pollutants in the urban atmosphere (Yang et al., 2005, 2007; Wang et al., 2010; May et al., 2014; Grivas et al., 2018; Dhital et al., 2019; Lin et al., 2019). According to an estimate of World Urbanization Prospects 2018, 55.3\% of the global population is already living in urban areas (UN, 2018) where the population is usually exposed to high levels of pollutants emitted from road traffic (Dallmann et al., 2014; Liu et al., 2017). Commuters and drivers are potentially exposed to direct emissions from vehicles (Dallmann et al., 2014; Dhital et al., 2014; Gupta and

\footnotetext{
* Corresponding author.

Tel.: +886 968674154; Fax: +886-4-23742365

E-mail address: nbdhital@gmail.com
}

Elumalai, 2019; Shen and Gao, 2019). Inhalation and respiratory deposition of the fine particulates $\left(\mathrm{PM}_{2.5}\right)$ pose threats to human health and cause higher mortalities and morbidities (WHO, 2006; Lipfert, 2017; Yang et al., 2017; Wang et al., 2018; Zhang et al., 2018). Moreover, PM in vehicle exhaust has been linked to several adverse health impacts, including cardiovascular diseases, lung impairment and cancer (Geller et al., 2006; Wu et al., 2017).

Emissions from mobile sources affect not only human health but also contribute to environmental problems such as acid rain and global warming (Geller et al., 2006). Concerns over atmospheric PM have also been increasing due to its importance in the global climate change (Huang et al., 2017). Water-soluble ions in fine particulates might disrupt the regional and global radiation balance due to their capability to absorb or scatter solar radiation and Earth's thermal radiation (Gopal et al., 2015).

Numerous factors such as fuel characteristics, operating conditions, engine types and emission control technologies would influence the chemical composition of exhaust particles (Jin et al., 2017; Hao et al., 2019). PM emitted by 
vehicles have been reported to contain a complex mixture of diverse species such as elemental carbon (EC), organic carbon (OC), ions and elements (Cheung et al., 2009; Oanh et al., 2010; Chiang et al., 2012; Alam et al., 2016; Wu et al., 2016; Jiang et al., 2017; Hao et al., 2019). PM may also contain several potentially toxic metals (Fujiwara et al., 2011). Thus, it is crucial to consider the chemical composition of $\mathrm{PM}_{2.5}$, in addition to its mass emission, to better assess its effects on human health and environment (Hao et al., 2019).

Diesel and gasoline vehicles differ greatly in their emission characteristics (Cheung et al., 2010; Hao et al., 2019). Several studies have been carried out on gasoline and diesel vehicle emissions (Yang et al., 2007; Cheung et al., 2010; May et al., 2014; Sonntag et al., 2014; Wu et al., 2016; Jin et al., 2017; Hao et al., 2019). However, only a few of them have compared the chemical compositions of exhaust particles of gasoline and diesel vehicles (Cheung et al., 2010; Hao et al., 2019). In this study, we investigated and compared the emission factors of $\mathrm{PM}_{2.5}$ and its chemical constituents (carbonaceous species, water-soluble ions and metal elements), together with the emission factors of regulated gaseous air pollutants $\left(\mathrm{THC}, \mathrm{CO}, \mathrm{NO}_{x}\right.$ ), in the exhaust of in-use gasoline and diesel vehicles based on dynamometer tests. The results of this study would provide valuable information for emission inventories and receptor modelling applications.

\section{METHODS}

\section{Vehicles and Fuels}

Eight in-use vehicles (model years 2006-2016) were selected for the experiment of which four were gasoline vehicles (abbreviated as G1, G2, G3 and G4) and the remaining were diesel vehicles (abbreviated as D1, D2, D3 and D4) (Table 1). The vehicles were selected to span a range of common gasoline and diesel vehicle types available in Taiwan. The test-vehicles included sedan cars, SUVs, light-duty trucks and heavy-duty trucks. The gasoline vehicles had engine displacement volumes ranging from 1,794 to $2,354 \mathrm{cc}$ and accumulated mileages ranging from 30,180 to $186,438 \mathrm{~km}$. Similarly, the displacement volume and the accumulated mileage of diesel vehicles ranged from 1,992 to $7,684 \mathrm{cc}$ and 45,848 to $257,284 \mathrm{~km}$, respectively. Gasoline vehicles were equipped with three-way catalytic convertors, while diesel vehicles were equipped with diesel oxidation catalysts. Moreover, diesel-SUV (D1) was also equipped with diesel particulate filter (DPF). G4 was the vehicle of Taiwan-Phase $\mathrm{V}$ emission standard, while the rest of test-vehicles were of Taiwan-Phase IV emission standard.

Motor unleaded gasoline (lead content $\leq 0.013 \mathrm{~g} \mathrm{~L}^{-1}$ ) and automotive diesel fuel supplied by CPC Corporation, Taiwan, were used for the gasoline and diesel vehicles, respectively. The average fuel densities (at $15^{\circ} \mathrm{C}$ ) were $751.9 \mathrm{~kg} \mathrm{~m}^{-3}$ (gasoline) and $833.6 \mathrm{~kg} \mathrm{~m}^{-3}$ (diesel). According to the fuel specifications provided by CPC Corporation, the sulfur content in both of the gasoline and diesel fuel was $\leq 10 \mathrm{mg} \mathrm{kg}^{-1}$.

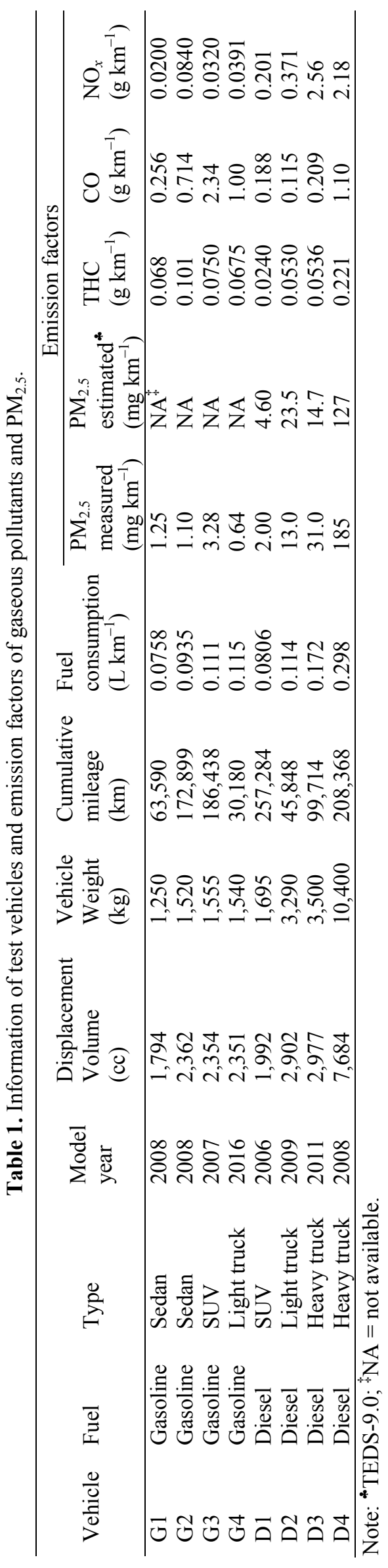




\section{Dynamometer and Driving Cycles}

Emissions of gasoline vehicles (G1, G2, G3 and G4) and light-duty diesel vehicles (D1 and D2) were tested in a chassis dynamometer system (Schenck 500/GS112/ V200/K400), while the emissions of heavy-duty diesel vehicles (D3 and D4) were tested in an engine dynamometer system with a DC-IV control (Schenck Dy NAS 350). The engine dynamometer had an automatic control system capable of contributing the maximum power of $335 \mathrm{~kW}$ and torque of $800 \mathrm{Nm}$. The sampling system consisted of a dilution tunnel, a constant volume sampling (CVS) unit (HORIBA CVS9300T) and a gas analyzer system (HORIBA MEXA9200D) (Fig. 1). The dilution air was passed through a High Efficiency Particulate Air (HEPA) filter to avoid sample contamination.

The gasoline vehicles (G1, G2, G3 and G4) and lightduty diesel vehicles (D1 and D2) were tested under the New European Driving Cycle (NDEC). The detailed description of the driving cycle can be found elsewhere (DieselNet, 2019a). Briefly, it is a combination of two different cycles namely, Urban Driving Cycle (UDC) and Extra UrbanDriving Cycle (EUDC). In a complete NDEC cycle, the vehicle is driven through $10.9314 \mathrm{~km}$ in $1,180 \mathrm{~s}$ with an average driving speed (excluding stops) of $43.10 \mathrm{~km} \mathrm{~h}^{-1}$. On the other hand, the heavy-duty diesel vehicles were tested under U.S. EPA FTP transient cycle procedure. The description of the test cycle can be found elsewhere (DieselNet, 2019b). The test cycle is based on the U.S. EPA Urban Dynamometer Driving Schedule (UDDS) for HeavyDuty Vehicles. It encompasses a cold start after 'parking' the engine, and then idling, acceleration and deceleration phases. Different speeds and loads are sequenced to simulate real-world driving patterns. The first phase is followed by the second recurrence that constitutes a hot-start after pausing for 1,200 s upon the completion of the first phase. Samples for cold- and hot-start phases were collected separately. The composite emission factor was obtained by using a weighting factor of $1 / 7$ and $6 / 7$ for cold- and hot- start emissions, respectively. The equivalent distance of the test cycle $(10.3 \mathrm{~km})$ was used to calculate emission factors. Detailed information can be referred to Yang et al. (2007).

\section{Sampling Strategy and Measurement of Pollutants}

The exhaust of gasoline and diesel vehicles were sampled based on the CVS principle. The exhaust pipe of the automobile was connected directly to the dilution system. The exhaust of gasoline and light-duty diesel vehicles was fed into a $11.5 \mathrm{~m}$ long dilution tunnel with the diameter of $0.305 \mathrm{~m}$. For heavy-duty diesel engines, a dilution tunnel of $9.17 \mathrm{~m}$ length and $0.610 \mathrm{~m}$ diameter was used. A Spencer blower was used to draw dilution air into the dilution tunnel. The quantity of air in the dilution tunnel was controlled by critical flow venturi.

The diluted exhaust gas was collected in Tedlar sampling bag (SKC Inc.) and analyzed for gaseous pollutants. $\mathrm{CO}$ and $\mathrm{CO}_{2}$ were measured by non-dispersive infrared absorption (NDIR) (HORIBA, Model AIA-120 analyzer). THC and $\mathrm{NO}_{x}$ were measured by heated flame ionization detector (FID) (HORIBA FIA-120) and chemiluminescence (HORIBA CLA-155), respectively. The gaseous pollutants were also measured in the background (indoor air) during each test and the background correction was applied to the test results.

A cyclone separator was used to separate $\mathrm{PM}_{2.5}$ fraction from the exhaust particles. The $\mathrm{PM}_{2.5}$ fraction was collected on a quartz filter (diameter $=47 \mathrm{~mm}$ ) at the temperature below $52^{\circ} \mathrm{C}$. The sample was analyzed for the mass concentration and the chemical composition. The filters were conditioned at $20-23^{\circ} \mathrm{C}$ temperature and 30 $40 \%$ relative humidity for 24 hours before and after sampling. The weights of conditioned filters were measured (Sartorius balance, model Cubis 6.6S-DF, sensitivity $10^{-6} \mathrm{~g}$ ) and emission factors were calculated.

In addition to the direct measurement, the $\mathrm{PM}_{2.5}$ emission factors for diesel vehicles were estimated by using an equation suggested by Taiwan EPA (2017) in Taiwan Emission Data System (TEDS)-9.0 (Eq. (1)).

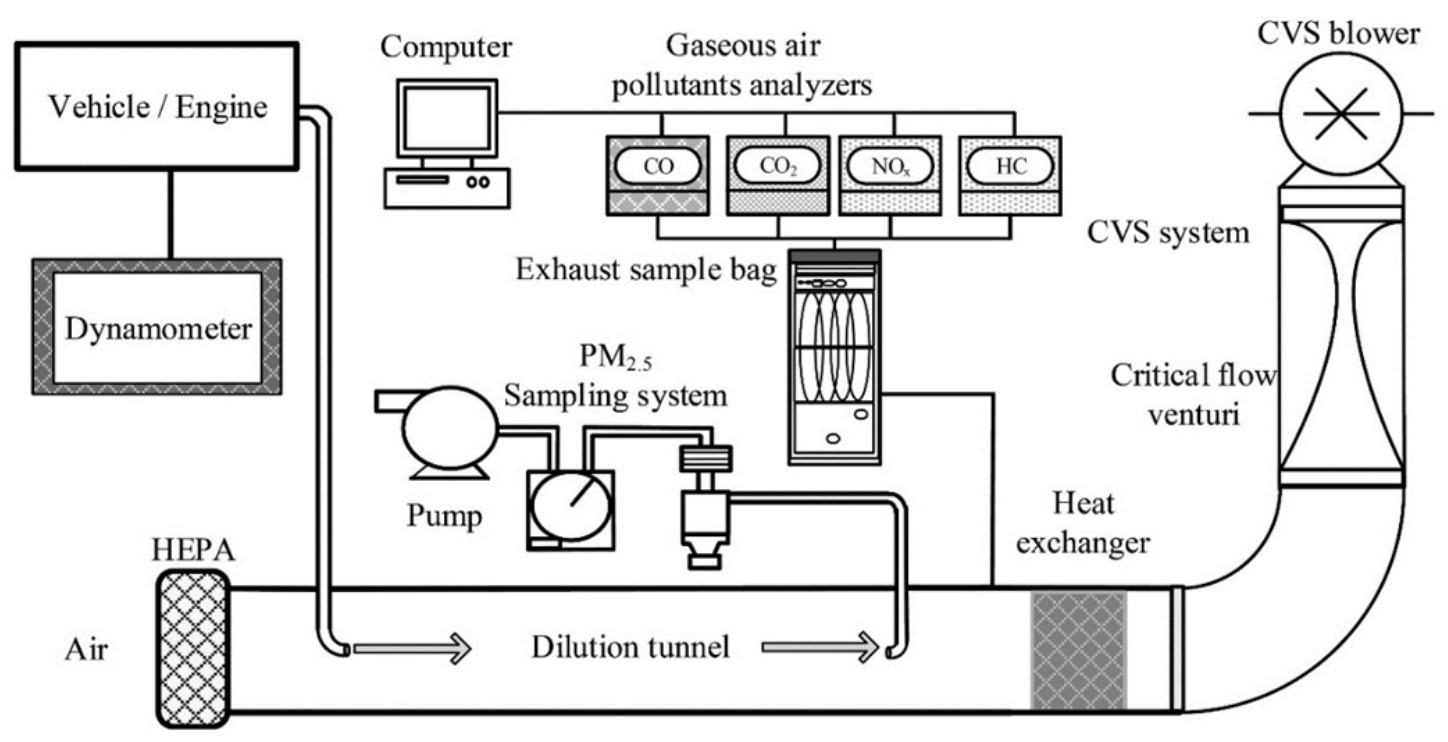

Fig. 1. Schematic of the experimental setup. 


$$
\mathrm{PM}_{2.5}\left(\mathrm{~g} \mathrm{~km}^{-1}\right)=0.92 \times\left(Z M L+\frac{D E T \times C U M M I L}{10,000}\right)
$$

In Eq. (1), ZML represents the zero-mileage emission level in $\mathrm{g} \mathrm{km}^{-1}$ (provided by the manufacturer); DET is the deterioration factor defined as the increase in emission factor $\left(\mathrm{g} \mathrm{km}^{-1}\right)$ per $10,000 \mathrm{~km}$ (provided by the manufacturer); CUMMIL is the accumulated mileage of vehicles in $\mathrm{km}$; the correction factor $(0.92)$ represents the fraction of $\mathrm{PM}_{2.5}$ in total suspended particulates (TSP) emitted by diesel vehicles.

\section{Chemical Analysis of $\mathrm{PM}_{2.5}$}

The $\mathrm{PM}_{2.5}$ filter with sample was cut into four equal pieces for the analysis of OC, EC, water-soluble ions and metal elements, respectively. Thermal/optical carbon analyzer (DRI, model 2001, Reno, USA) was used for analyzing $\mathrm{OC}$ and EC following the Interagency Monitoring of Protected Visual Environments (IMPROVE) protocol. Water-soluble ions were extracted from the filter sample in distilled deionized water by using an ultrasonicator (Branson, model 5210). The extract was passed through a $0.4 \mu \mathrm{m}$ filter and analyzed for water-soluble ions by using ion chromatography (IC, Dionex, model DX-120). The eluent for cation analysis was $20 \mathrm{mM}$ methane sulfonic acid while it was $1.8 \mathrm{mM} \mathrm{Na}_{2} \mathrm{CO}_{3} / 1.7 \mathrm{mM} \mathrm{NaHCO}$ for anion analysis. Calibration lines were made by using cation standard from AccuStandard (210125090) and anion standard from High-Purity Standards (1033506 and 1034819). The coefficient of determination $\left(\mathrm{R}^{2}\right)$ of the calibration equations were more than 0.995 . For elemental analysis, a part of $\mathrm{PM}_{2.5}$ filter sample was digested in a 1:3 mixture of $\mathrm{HNO}_{3}$ and $\mathrm{HCl}$ on a hot plate for 1 hour. The digested sample was analyzed for the following elements: Al, Ca, $\mathrm{Fe}, \mathrm{Mg}, \mathrm{Mn}, \mathrm{Na}, \mathrm{K}, \mathrm{Pb}, \mathrm{Zn}, \mathrm{Ni}, \mathrm{V}, \mathrm{Cu}, \mathrm{Cd}, \mathrm{Mo}, \mathrm{Co}, \mathrm{Se}, \mathrm{Sr}$, $\mathrm{As}, \mathrm{Ba}, \mathrm{Sb}$ and $\mathrm{Sn}$. An inductively coupled plasma-optical emission spectrometer (ICP-OES, Thermo Scientific, model iCAP 6000 Series) was used for the analysis of metal elements. Details of the analytical method can be found elsewhere (Yang et al., 2018). Laboratory blanks were run for the quality control. Blank concentrations were negligible compared with the corresponding sample concentrations.

\section{RESULTS AND DISCUSSION}

\section{Emission Factors of Regulated Gaseous Pollutants}

The average emission factors of THC for the gasoline and diesel vehicles were $0.0779 \mathrm{~g} \mathrm{~km}^{-1}\left(0.0675-0.101 \mathrm{~g} \mathrm{~km}^{-1}\right)$ and $0.0879 \mathrm{~g} \mathrm{~km}^{-1}\left(0.0240-0.221 \mathrm{~g} \mathrm{~km}^{-1}\right)$, respectively (Table 1). The highest THC emission factor was recorded for the diesel vehicle with the highest engine displacement (D4), whereas the lowest THC emission factor was observed for the diesel vehicle with the lowest engine displacement (D1). The emission factor of THC $(0.20 \pm$ $0.18 \mathrm{~g} \mathrm{~km}^{-1}$ ) for gasoline cars reported by Kerbachi et al. (2017) was slightly higher than the respective emission factors obtained in the preset study. The average CO emission factors were $1.08 \mathrm{~g} \mathrm{~km}^{-1}(0.256-2.43) \mathrm{g} \mathrm{km}^{-1}$ and
$0.403 \mathrm{~g} \mathrm{~km}^{-1}(0.115-1.10) \mathrm{g} \mathrm{km}^{-1}$ for gasoline and diesel vehicles, respectively, which were comparable to the $\mathrm{CO}$ emission factor $\left(0.81 \pm 0.69 \mathrm{~g} \mathrm{~km}^{-1}\right)$ reported by Kerbachi et al. (2017). The highest and the lowest CO emission factors were observed for the gasoline vehicle with the highest accumulated mileage (G3) and the diesel vehicle with the lowest accumulated mileage (D2), respectively. The average $\mathrm{CO}$ emission factor for gasoline vehicles was about 2.7 times of that for diesel vehicles. Schmitz et al. (2000) tested emissions of gasoline cars (with three-way catalyst) and diesel cars, and their results also show that the average $\mathrm{CO}$ emission factors for gasoline cars was about 3 times of that for diesel cars. Gasoline vehicles with higher accumulated mileages have been reported to have higher CO emission factors (Ntziachristos and Samaras, 2000) which was consistent with the results of the present study. Unlike $\mathrm{CO}$, the average $\mathrm{NO}_{x}$ emission factor of gasoline vehicles $\left(0.0438 \mathrm{~g} \mathrm{~km}^{-1}\right)$ was less by a factor of 30 in comparison to that of diesel vehicles $\left(1.33 \mathrm{~g} \mathrm{~km}^{-1}\right)$. The $\mathrm{NO}_{x}$ emission factors of diesel vehicles obtained in the present study were comparable to those for pre-LEV and LEV-I vehicles (May et al., 2014). Chiang et al. (2012) tested the emissions of light-duty diesel vehicles (without emission control equipment) with engine displacement ranging from 2,184 to $2,835 \mathrm{cc}$. The average emission factors of THC, $\mathrm{CO}$ and $\mathrm{NO}_{x}$ have been reported to be $0.171 \mathrm{~g} \mathrm{~km}^{-1}$ $\left(0.066-0.371 \mathrm{~g} \mathrm{~km}^{-1}\right), 1.395 \mathrm{~g} \mathrm{~km}^{-1}\left(0.671-2.650 \mathrm{~g} \mathrm{~km}^{-1}\right)$ and $1.735 \mathrm{~g} \mathrm{~km}^{-1}\left(1.001-3.983 \mathrm{~g} \mathrm{~km}^{-1}\right.$ ), respectively (Chiang et al., 2012), which were slightly higher than the respective emission factors obtained in the present study. This might be the effect of catalytic convertors used in diesel vehicles of the present study.

\section{Mass Emission Factor of PM 2.5}

The average $\mathrm{PM}_{2.5}$ emission factors for gasoline and diesel vehicles were $1.57 \mathrm{mg} \mathrm{km}^{-1}\left(0.643-3.28 \mathrm{mg} \mathrm{km}^{-1}\right)$ and $57.8 \mathrm{mg} \mathrm{km}^{-1}\left(2.00-185 \mathrm{mg} \mathrm{km}^{-1}\right)$, respectively (Table 1). Among gasoline vehicles, the highest $\mathrm{PM}_{2.5}$ emission factor was observed for the vehicle with the highest accumulated mileage (G3), whereas the lowest $\mathrm{PM}_{2.5}$ emission factor was observed for the relatively newer vehicle with the lowest accumulated mileage (D4). Among diesel vehicles, the highest emission factor was obtained for the heavy-duty diesel truck with the highest engine displacement volume (D4), while the lowest emission factor was recorded for the vehicle with the lowest engine displacement volume (D1). Moreover, D1 was also installed with DPF which might have effectively reduced the fine particulate emissions. Several previous studies have shown that DPF can reduce particulate emissions of diesel vehicles with high efficiency (Yang et al., 2005; Cheung et al., 2009; May et al., 2014). Among the heavyduty diesel trucks, the $\mathrm{PM}_{2.5}$ emission factor for D3 was lower than that for D4, mainly because of the smaller displacement volume, lower accumulated mileage and better fuel economy.

$\mathrm{Wu}$ et al. (2016) measured emissions on a portable emission measurement system for diesel trucks and the average $\mathrm{PM}_{2.5}$ emission factor was $85 \mathrm{mg} \mathrm{km}^{-1}$, which was 
comparable to the results of the present study. Chiang et al. (2012) reported the $\mathrm{PM}_{2.5}$ emission factor of $151 \mathrm{mg} \mathrm{km}^{-1}$ for light-duty diesel vehicles based on dynamometer tests which was fairly comparable to the emission factor of $\mathrm{PM}_{2.5}$ obtained for diesel trucks in the present study. Oanh et al. (2010) performed chassis dynamometer test for light-duty and heavy-duty diesel engines on models built between 1972 and 2005; the average $\mathrm{PM}_{2.5}$ emission factors (230 mg km${ }^{-1}$ for light-duty and $1761 \mathrm{mg} \mathrm{km}^{-1}$ for heavyduty diesel trucks) were several fold higher than those obtained in the present study. Dai et al. (2015) reported the average $\mathrm{PM}_{2.5}$ emission factor of $92.4 \pm 8.9 \mathrm{mg} \mathrm{km}^{-1}$ for on-road vehicles. Relatively newer model vehicles were tested in the present study (model year 2006-2016) which might be one of the major reasons for lower $\mathrm{PM}_{2.5}$ emission factors. The wide range of $\mathrm{PM}_{2.5}$ emission factors reported in the literature reflects differences in test methods, emission control devices, vehicle models and manufacture years, driving cycles, fuel quality and the rate of fuel consumption.

$\mathrm{PM}_{2.5}$ emission factors were estimated for diesel vehicles by using the method suggested by TEDS-9.0 (Table S1). The estimated emission factors were reasonably close to the measured emission factors (Table 1). Pearson correlation coefficient was calculated for the measured and estimated $\mathrm{PM}_{2.5}$ emissions factors of diesel vehicles, and a high degree of correlation was obtained $(\mathrm{R}=0.989, p=0.011)$ suggesting that the TEDS-9.0 method could be a reliable and cost-effective way for estimating the $\mathrm{PM}_{2.5}$ emission factors of diesel vehicles in Taiwan.

\section{Emission Factors of Chemical Constituents of PM ${ }_{2.5}$}

Average emission factors of detected chemical species have been calculated for gasoline and diesel vehicles (Table 2). The chemical constituents of $\mathrm{PM}_{2.5}$ have been discussed under three groups (carbonaceous species, watersoluble ions and metal elements) in the following sections.

\section{Carbonaceous Species}

The average emission factors of OC, EC and total carbon $(\mathrm{OC}+\mathrm{EC})$ for gasoline vehicles were $0.873 \mathrm{mg} \mathrm{km}^{-1}(0.378-$ $\left.2.09 \mathrm{mg} \mathrm{km}^{-1}\right), 0.365 \mathrm{mg} \mathrm{km}^{-1}\left(0.143-0.576 \mathrm{mg} \mathrm{km}^{-1}\right)$ and $1.24 \mathrm{mg} \mathrm{km}^{-1}\left(0.522-2.66 \mathrm{mg} \mathrm{km}^{-1}\right)$, respectively. For diesel vehicles, the average emission factors of OC, EC and total carbon were $10.8 \mathrm{mg} \mathrm{km}^{-1}\left(0.812-28.2 \mathrm{mg} \mathrm{km}^{-1}\right)$, $39.6 \mathrm{mg} \mathrm{km}^{-1}\left(0.875-131 \mathrm{mg} \mathrm{km}^{-1}\right)$ and $50.4 \mathrm{mg} \mathrm{km}^{-1}$ (1.69-159 $\mathrm{mg} \mathrm{km}^{-1}$ ), respectively (Table 2). The emission factors of carbonaceous species for diesel vehicles (except D1) were higher than those for gasoline vehicles (Fig. 2), and the result was in agreement with that of Cheung et al. (2009). The average emission factors of OC, EC and total carbon for a vehicle fleet consisting of light-duty, mediumduty and heavy-duty diesel trucks in Beijing, have been determined to be $27 \mathrm{mg} \mathrm{km}^{-1}\left(3-105 \mathrm{mg} \mathrm{km}^{-1}\right), 47 \mathrm{mg} \mathrm{km}^{-1}$ (13-95 mg km$\left.{ }^{-1}\right)$ and $74 \mathrm{mg} \mathrm{km}^{-1}\left(0.016-0.199 \mathrm{mg} \mathrm{km}^{-1}\right)$, respectively (Wu et al., 2016). The range of emission factors obtained for diesel vehicles in the present study were fairly comparable to those reported by $\mathrm{Wu}$ et al. (2016). However, other studies on the emissions of light-duty and heavy-duty diesel vehicles (Oanh et al., 2010, Chiang et $a l .$, 2012) have reported the emission factors of carbonaceous species, several times higher than those in the present study. One of the major reasons for this difference could be the vehicle model year as their test vehicles were of older model years (1992-2005) compared to those tested in the present study (Oanh et al., 2010, Chiang et al., 2012).

The average OC/EC ratios for gasoline and diesel vehicles were found to be $2.29(1.16-3.62)$, and 0.571 (0.215$0.929)$, respectively. The $\mathrm{OC} / \mathrm{EC}$ ratios were $>1$ for all gasoline vehicles and $<1$ for all diesel vehicles (Fig. 2). Similar results have been found for a Euro 3 compliant Toyota Corolla gasoline car $(\mathrm{OC} / \mathrm{EC}=19)$ and a Euro 4 compliant Accord diesel car $(\mathrm{OC} / \mathrm{EC}=0.25)$ (Cheung et al., 2010). May et al. (2014) also showed OC/EC $<1$ for non-DPF diesel vehicles. The OC/EC ratios have been found to be 1.16 for gasoline vehicles and 0.417 for diesel vehicles (U.S. EPA, 2007), 6.08 for light-duty gasoline vehicles and 1.52 for light-duty diesel vehicles (Hao et al., 2019), 0.575 for diesel trucks (Wu et al., 2016), 0.514 for light-duty diesel trucks (Chiang et al., 2012), 0.428 for heavy-duty diesel vehicles (Zhang et al., 2015), 0.435 for light-duty diesel trucks and 0.277 for heavy-duty diesel trucks (Oanh et al., 2010). Most of these results have shown $\mathrm{OC} / \mathrm{EC}>1$ for gasoline vehicles and $\mathrm{OC} / \mathrm{EC}<1$ for diesel vehicles which were in agreement with the results of the present study. Thus, OC/EC ratio in exhaust particles could be a good indicator of gasoline and diesel vehicle emissions.

\section{Water-soluble Ions}

Emission factors of water-soluble ions in fine particulates emitted by gasoline and diesel vehicles have been presented in Fig. 3. Diesel vehicle exhausts had higher emission factors for most of the ionic species than the gasoline vehicle exhausts. Relatively higher emission factors of water-soluble ions were obtained for the high-mileage gasoline vehicle (G3) and heavy-duty diesel trucks (D3 and D4) (Fig. 3). Emission factors of the sum of water-soluble ions for gasoline and diesel vehicles ranged from 2.74 to $74.0 \mu \mathrm{g} \mathrm{km}^{-1}$ and 9.46 to $310 \mu \mathrm{g} \mathrm{km}^{-1}$, respectively. The average emission factors for the water-soluble ions were $25.8 \mu \mathrm{g} \mathrm{km}^{-1}$ (gasoline vehicles) and $108 \mu \mathrm{g} \mathrm{km}^{-1}$ (diesel vehicles). Among the analyzed ionic species, $\mathrm{Ca}^{2+}\left(63.5 \mu \mathrm{g} \mathrm{km}^{-1}\right)$ and $\mathrm{SO}_{4}{ }^{2-}$ $\left(8.83 \mu \mathrm{g} \mathrm{km}^{-1}\right)$ were the major ions in gasoline vehicle exhausts (Table 2). Cheung et al. (2009) has also reported $\mathrm{SO}_{4}{ }^{2-}$ as the inorganic ion with the highest emission factor in the PM emitted by gasoline car equipped with three-way catalyst. For diesel vehicles, $\mathrm{NO}_{3}^{-}(63.7 \mu \mathrm{g} \mathrm{km}), \mathrm{Ca}^{2+}$ $\left(21.9 \mu \mathrm{g} \mathrm{km}^{-1}\right)$ and $\mathrm{SO}_{4}{ }^{2-}\left(20.3 \mu \mathrm{g} \mathrm{km}^{-1}\right)$ were the top three water-soluble ions in terms of their average emission factors (Table 2). These three ionic species $\left(\mathrm{NO}_{3}{ }^{-}, \mathrm{Ca}^{2+}\right.$ and $\left.\mathrm{SO}_{4}{ }^{2-}\right)$ have been reported as the top three water-soluble ions in $\mathrm{PM}_{2.5}$ emitted by diesel vehicles (Oahn et al., 2010; Chiang et al., 2012; Wu et al., 2016). Similar results have also been reported by Hao et al. (2019). The thermal $\mathrm{NO}_{x}$ formed during high temperature combustion of diesel fuel might be the major contributor of nitrate ions. Moreover, likely sources of $\mathrm{Ca}^{2+}$ and $\mathrm{SO}_{4}{ }^{2-}$ could be lubricant oil and the sulfur in the diesel fuel (Vogt et al., 2003; Cheung et al., 2009; Hao et al., 2019). The oxidation catalyst in diesel 


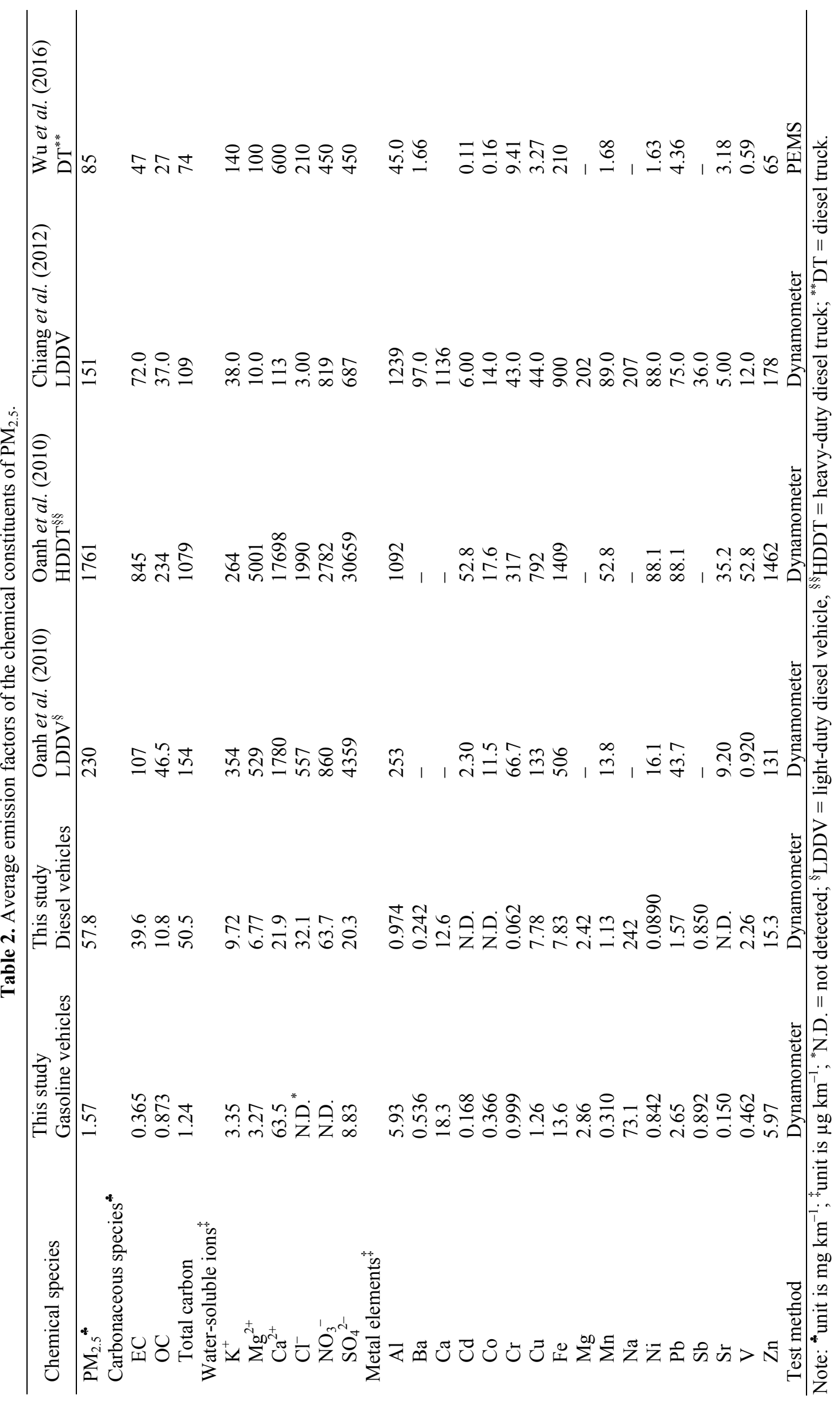




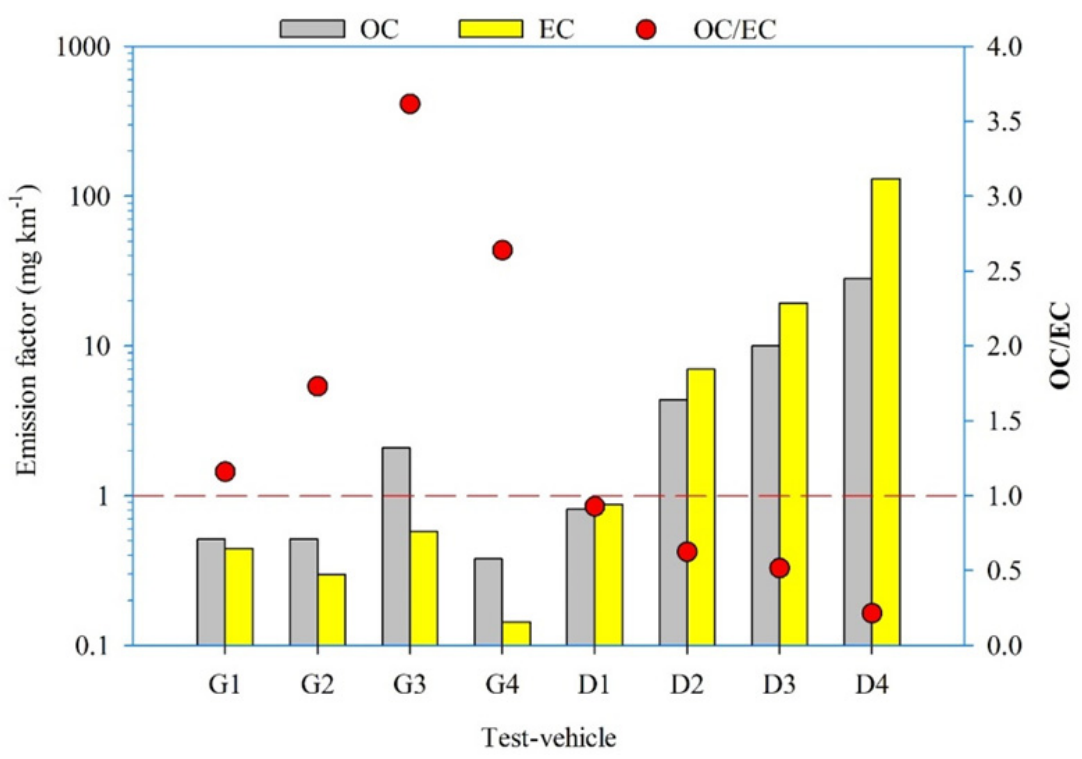

Fig. 2. Emission factors of carbonaceous species for gasoline and diesel vehicles.

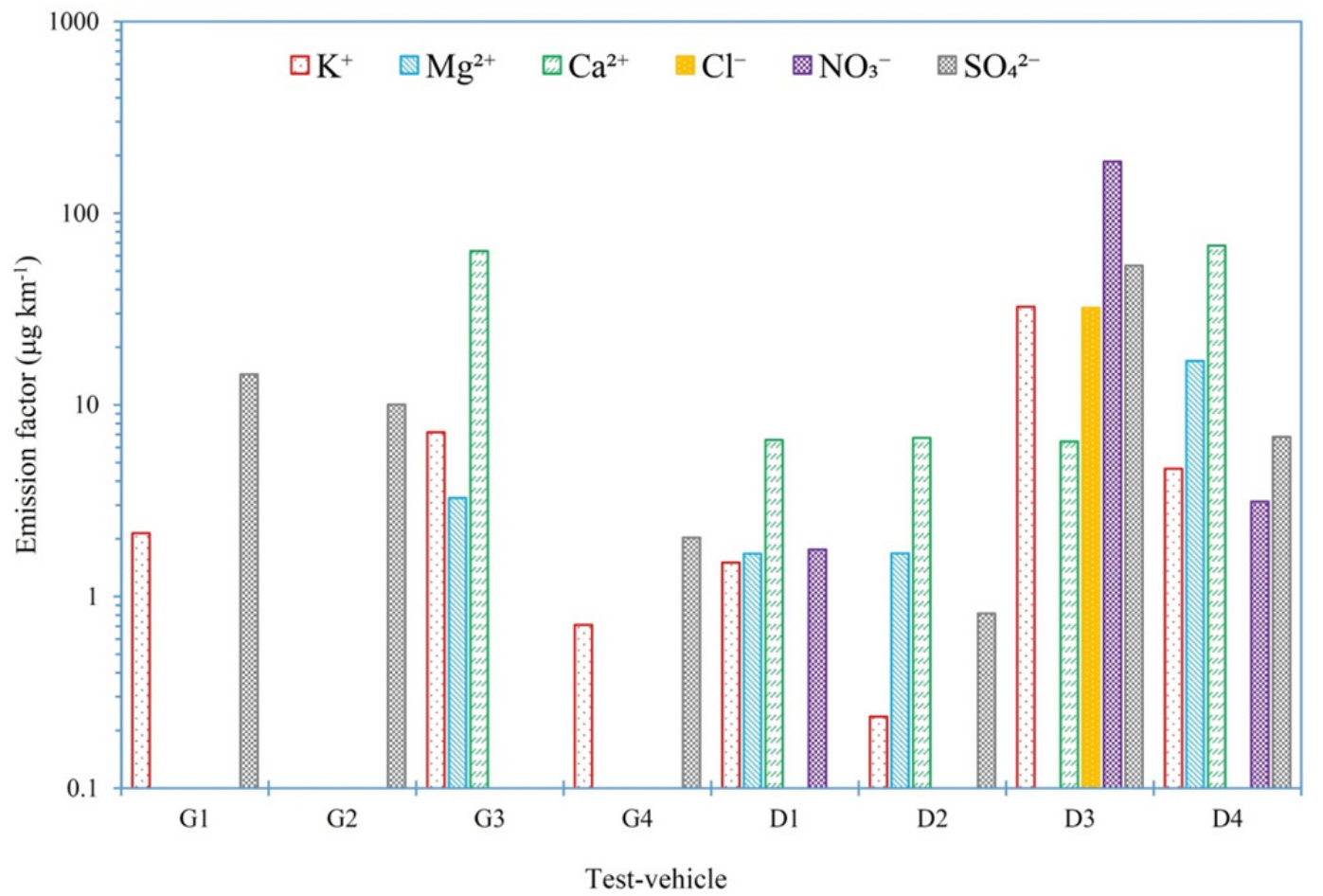

Fig. 3. Emission factors of water-soluble ions for gasoline and diesel vehicles.

vehicles might also have positive effect on $\mathrm{SO}_{4}{ }^{2-}$ formation (Maricq et al., 2002). Ionic species, such as $\mathrm{SO}_{4}{ }^{2-}$ and $\mathrm{NO}_{3}{ }^{-}$, in the ambient PM are mostly contributed by traffic related emissions (Arhami et al., 2017) and form the important species during smog events (Kim et al., 2007). As discussed earlier, these were the major water soluble ions among others in the $\mathrm{PM}_{2.5}$ emitted by gasoline and diesel vehicles. Thus, controlling the ambient concentrations of these species would require a primary focus on vehicular emissions.

\section{Metal Elements}

$\mathrm{PM}_{2.5}$ samples were analyzed for 21 target elements, and a total of 17 elements were detected in at least one sample. Emission factors of the sum of detected elements for gasoline and diesel vehicles ranged from 31.1 to $240 \mu \mathrm{g}$ $\mathrm{km}^{-1}$ and 5.18 to $747 \mu \mathrm{g} \mathrm{km}^{-1}$, respectively. The average emission factor of metal elements for diesel vehicles $(225$ $\mu \mathrm{g} \mathrm{km}^{-1}$ ) was approximately two times of that for gasoline vehicles $\left(106 \mu \mathrm{g} \mathrm{km}^{-1}\right)$. The average emission factors of individual elements have been presented in Table 2 . 
$\mathrm{Na}, \mathrm{Ca}, \mathrm{Fe}, \mathrm{Zn}$ and $\mathrm{Al}$ were the top five metal elements in terms of their emission factors for gasoline vehicles. Other similar studies have also found $\mathrm{Ca}, \mathrm{Fe}, \mathrm{Al}$ and $\mathrm{Zn}$ as the major metal elements in gasoline vehicle particles (Cheung et al., 2010; Hao et al., 2019). For diesel vehicles, the most abundant metal elements with highest average emission factors were $\mathrm{Na}, \mathrm{Ca}, \mathrm{Zn}, \mathrm{Cu}$ and $\mathrm{V}$. Some of the major metal elements in diesel vehicle particles are $\mathrm{Al}, \mathrm{Ca}$, $\mathrm{Cr}, \mathrm{Cu}, \mathrm{Fe}, \mathrm{Na}, \mathrm{Mg}$, and $\mathrm{Zn}$ (Cheung et al., 2010; Oanh et al., 2010; Chiang et al., 2012; Wu et al., 2016; Pervez et al., 2018; Hao et al., 2019). The metal elements in the vehicular exhaust is mostly contributed by fuels, lubricants and the abrasion of engine components (Wang et al., 2003; Hao et al., 2019). $\mathrm{Mn}, \mathrm{Cr}, \mathrm{Cu}, \mathrm{Ni}$ and $\mathrm{Pb}$ were the metal elements with relatively low emission factors. One of the likely sources of Mn could be the gasoline itself because $\mathrm{Mn}$ is used as a knock improver in the gasoline fuel (Cheung et al., 2010; Hao et al., 2019).

Some of the trace elements detected in the exhaust particles, such as $\mathrm{Cd}, \mathrm{Cr}, \mathrm{Pb}$ and $\mathrm{Sb}$, are potentially toxic to human health (Fujiwara et al., 2011; Sen et al., 2016; Sha et al., 2019). Emissions from mobile sources contribute a sizable fraction of atmospheric concentration of these species (Sen et al., 2016; Sha et al., 2019). Thus, controlling mobile source emissions would help substantially to reduce the ambient concentrations of these toxic species.

\section{Source Profiles of $\mathrm{PM}_{2.5}$}

Chemical source profiles of $\mathrm{PM}_{2.5}$ for gasoline and diesel vehicles have been prepared and presented in the supplementary material (Table S1). The proportions of EC, $\mathrm{OC}$, water-soluble ions and metal elements in $\mathrm{PM}_{2.5}$ were calculated and compared for different types of vehicles (Fig. 4). The $\mathrm{PM}_{2.5}$ mass was dominated by carbonaceous species in all test-vehicles. The average proportions of EC and $\mathrm{OC}$ in gasoline vehicle exhausts were $25.6 \%$ and $52.6 \%$, respectively, while those in diesel vehicle exhausts were $57.7 \%$ and $30.4 \%$, respectively. These findings were fairly comparable to those of previous studies for respective vehicle types (Gillies and Gertler, 2000; U.S. EPA, 2007; Oanh et al., 2010; Chiang et al., 2012; Zhang et al., 2015; Wu et al., 2016). In an average, the total carbon accounted for $78.2 \%(73.9-81.2 \%)$ of $\mathrm{PM}_{2.5}$ mass for gasoline vehicles. The proportion of total carbon have been reported to be $78.5 \%$ (SPECIATE No. 4931) for gasoline vehicles (U.S. EPA, 2007) which was nearly equal to that obtained in the present study. Similarly, the average proportion of total carbon was $88.1 \%(84.3-94.6 \%)$ for diesel vehicles. The proportions of total carbon in $\mathrm{PM}_{2.5}$ have been found to be $87.4 \%$ (SPECIATE No. 4894) for diesel vehicles (U.S. EPA, 2007), $66.7 \%$ and $61.3 \%$ for light-duty and heavy-duty diesel trucks (Oanh et al., 2010), 72.2\% for light-duty diesel vehicles (Chiang et al., 2012), 87.1\% for diesel trucks (Wu et al., 2016) and 85.8\% for heavy-duty diesel vehicles (Zhang et al., 2015) which were comparable to those of the present study.

The sum of six water-soluble ions analyzed in the present study accounted for $0.426-2.25 \%$ of $\mathrm{PM}_{2.5}$ mass in gasoline

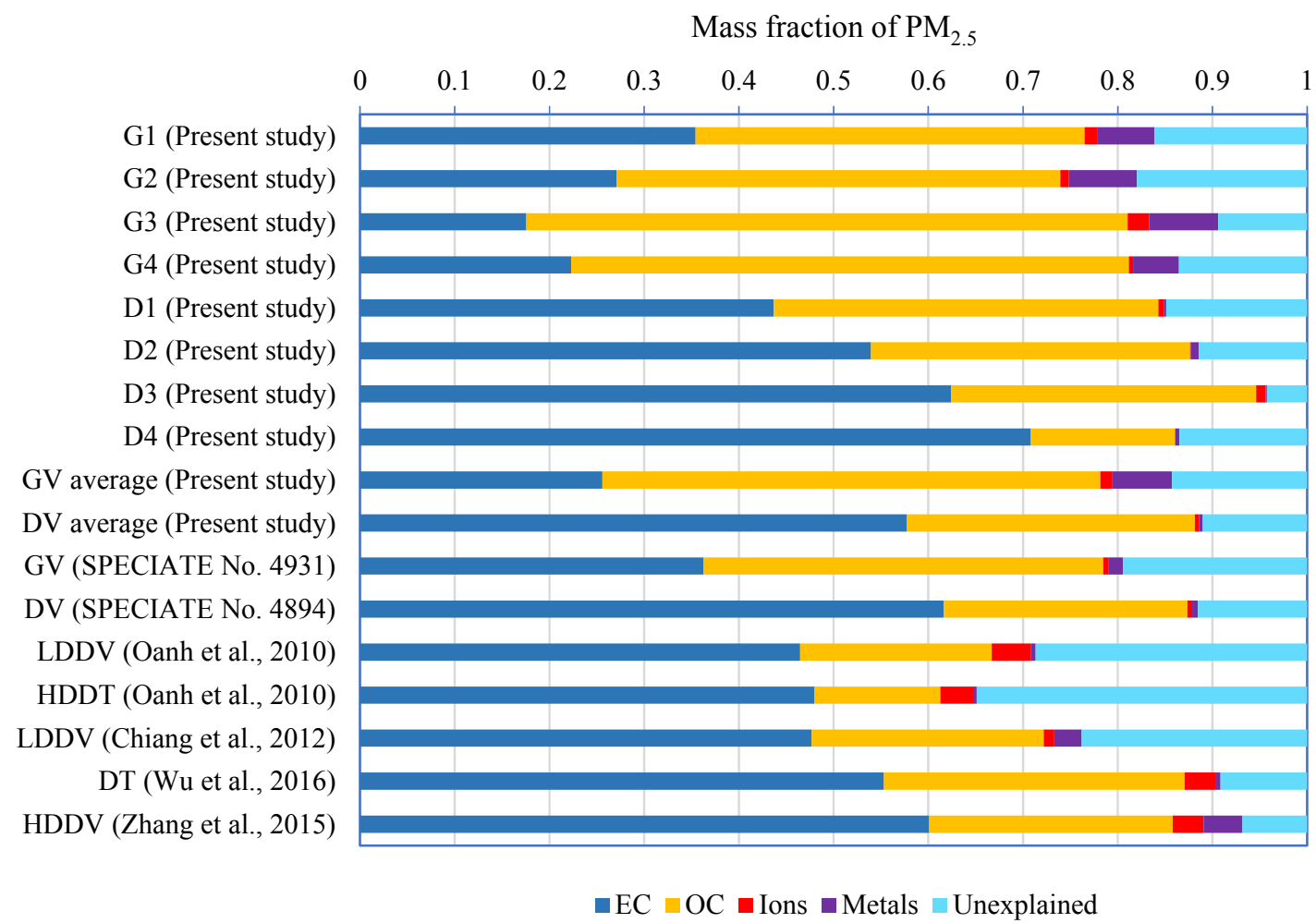

Fig. 4. Proportions of OC, EC, water-soluble ions and metal elements in $\mathrm{PM}_{2.5}$ emitted by gasoline and diesel vehicles; $\mathrm{GV}=$ gasoline vehicle, $\mathrm{DV}=$ diesel vehicle, $\mathrm{LDDV}=$ low-duty diesel vehicle, $\mathrm{HDDV}=$ heavy-duty diesel vehicle, $\mathrm{DT}=$ diesel truck. 
vehicle exhaust, while it contributed $0.0536-1.00 \%$ of $\mathrm{PM}_{2.5}$ mass in diesel vehicle exhaust. The U.S. EPA SPECIATE profiles show that these ions accounted for $0.600 \%$ (gasoline vehicles) and $0.518 \%$ (diesel vehicles) of $\mathrm{PM}_{2.5}$ mass (U.S. EPA, 2007). The proportions of the sum of analyzed ions in $\mathrm{PM}_{2.5}$ emitted by diesel vehicles have been found to be $1.11 \%$ to $4.10 \%$ in various previous studies (Oanh et al., 2010; Chiang et al., 2012; Zhang et al., 2015; Wu et al., 2016).

Metal elements (17 elements detected in the present study) contributed $4.84-7.31 \%$ and $0.123-0.819 \%$ of $\mathrm{PM}_{2.5}$ emitted by gasoline and diesel vehicles, respectively. The mass contributions of these metal elements are $1.48 \%$ and $0.592 \%$ for gasoline and diesel vehicles, respectively (U.S. EPA, 2007). Similarly, several previous studies have shown that the proportions of sum of elements in $\mathrm{PM}_{2.5}$ were $0.312-4.11 \%$ for different types of diesel vehicles (Oanh et al., 2010; Chiang et al., 2012; Zhang et al., 2015; Wu et al., 2016). These results show that the elemental fractions in $\mathrm{PM}_{2.5}$ were higher for gasoline vehicles than for diesel vehicles.

\section{CONCLUSIONS}

This study investigated a detailed chemical composition of fine particulate matter and the emission factors of gaseous and particulate pollutants for gasoline and diesel vehicles based on dynamometer tests. Vehicles with bigger engines and higher accumulated mileages had higher emission factors of gaseous pollutants. The average $\mathrm{PM}_{2.5}$ emission factors for gasoline and diesel vehicles were $1.57 \mathrm{mg} \mathrm{km}^{-1}$ and $57.8 \mathrm{mg} \mathrm{km}^{-1}$, respectively. The carbonaceous species (OC and EC) were the most dominant components of $\mathrm{PM}_{2.5}$ which accounted for $78.2 \%$ (gasoline vehicle) and $88.1 \%$ (diesel vehicle) of $\mathrm{PM}_{2.5}$ mass. The $\mathrm{OC} / \mathrm{EC}$ ratio was found to be a good indicator of gasoline vehicle emissions $(\mathrm{OC} / \mathrm{EC}>1)$ and diesel vehicle emissions $(\mathrm{OC} / \mathrm{EC}<1)$. The average emission factors of sum of water-soluble ions were $25.8 \mu \mathrm{g} \mathrm{km}^{-1}$ and $108 \mu \mathrm{g} \mathrm{km}^{-1}$ for gasoline and diesel vehicles, respectively. $\mathrm{SO}_{4}{ }^{2-}$ and $\mathrm{NO}_{3}{ }^{-}$ were the important ionic species with relatively higher emission factors in $\mathrm{PM}_{2.5}$ emitted by gasoline and diesel vehicles. The average emission factors of metal elements were $106 \mu \mathrm{g} \mathrm{km}^{-1}$ (gasoline vehicles) and $225 \mu \mathrm{g} \mathrm{km}^{-1}$ (diesel vehicles), while some the toxic elements detected in the exhaust particles were $\mathrm{Cd}, \mathrm{Cr}, \mathrm{Pb}$ and $\mathrm{Sb}$. The chemical composition of fine particulates reported in this study would be useful for inventory compilation and receptor modelling applications.

\section{ACKNOWLEDGEMENTS}

The authors would like to acknowledge ARTC (The Automotive Research and Testing Center), Taiwan, for providing emission testing facility. This research was funded by Taiwan EPA (EPA-106-FA13-03-D047).

\section{SUPPLEMENTARY MATERIAL}

Supplementary data associated with this article can be found in the online version at http://www.aaqr.org.

\section{REFERENCES}

Alam, K., Haheen, K., Blaschke, S.T., Chishtie, F., Khan, H.U. and Haq, B.S. (2016). Classification of aerosols in an urban environment on the basis of optical measurements. Aerosol Air Qual. Res. 16: 2535-2549.

Cheung, K., Polidori, A., Ntziachrists, L., Tzamkiozis, T., Samaras, Z., Cassee, F.R., Gerlofs, M. and Sioutas, C. (2009). Chemical characteristics and oxidative potential of particulate matter emissions from gasoline, diesel, and biodiesel cars. Environ. Sci. Technol. 43: 6334-6340.

Cheung, K.L., Ntziachristos, L., Tzamkiozis, T., Schauer, J.J., Samaras, Z., Moore, K.F. and Sioutas, C. (2010). Emissions of particulate trace elements, metals and organic species from gasoline, diesel, and biodiesel passenger vehicles and their relation to oxidative potential. Aerosol Sci. Technol. 44: 500-513.

Chiang, H., Lai, Y. and Chang, S. (2012). Pollutant constituents of exhaust emitted from light duty diesel vehicles. Atmos. Environ. 47: 399-406.

Dai, S., Bil, X., Chan, L.Y., He, J., Wang, B., Wang, X., Peng, P., Sheng, G. and Fu, J. (2015). Chemical and stable carbon isotopic composition of $\mathrm{PM}_{2.5}$ from on-road vehicle emissions in the PRD region and implications for vehicle emission control policy. Atmos. Chem. Phys. 15: 3097-3108.

Dallmann, T.R., Onasch, T.B., Kirchstetter, T.W., Worton, D.R., Fortner, E.C., Herndon, S.C., Wood, E.C., Franklin, J.P., Worsnop, D.R., Goldstein, A.H. and Harley, R.A. (2014). Characterization of particulate matter emissions from on-road gasoline and diesel vehicles using a soot particle aerosol mass spectrometer. Atmos. Chem. Phys. 14: 7585-7599.

Dhital, N.B., Hung, W.T. and Byanju, R.M. (2014). Air pollution inside public transport vehicles of Kathmandu Valley. Nepal J. Environ. Sci. 2: 35-41.

Dhital, N.B., Yang, H.H., Wang, L.C., Hsu, Y.T., Zhang, H.Y., Young, L.H. and Lu, J.H. (2019). VOCs emission characteristics in motorcycle exhaust with different emission control devices. Atmos. Pollut. Res., in Press, doi: 10.1016/j.apr.2019.04.007.

DieselNet (2019a). Emission test cycles: ECE 15 + EUDC/ NEDC. https://www.dieselnet.com/standards/cycles/ece _eudc.php; Last Access: 17 May, 2019.

DieselNet (2019b). Emission test cycles: Heavy-duty FTP transient cycle. https://www.dieselnet.com/standa rds/cycles/ftp_trans.php; Last Access: 17 May, 2019.

Fraser, M.P., Lakshmanan, K., Fritz, S.G. and Ubanwa, B. (2002). Variation in composition of fine particulate emissions from heavy-duty diesel vehicles. J. Geophys. Res. 107: ICC8/1-ICC8/6.

Fujiwara, F., Rebagliati, R.J., Marrero, J., Gómez, D. and Smichowski, P. (2011). Antimony as a traffic-related element in size-fractionated road dust samples collected in Buenos Aires. Microchem. J. 97: 62-67.

Geller, M.D., Ntziachristos, L., Mamakos, A., Samaras, Z., Schmitz, D.A., Froines, J.R. and Sioutas, C. (2006). 
Physicochemical and redox characteristics of particulate matter (PM) emitted from gasoline and diesel passenger cars. Atmos. Environ. 40: 6988-7004.

Gillies, J.A. and Gertler, A.W. (2000). Comparison and evaluation of chemically speciated mobile source $\mathrm{PM}_{2.5}$ particulate matter profiles. J. Air Waste Manage. Assoc. 50: 1459-1480.

Gopal, K.R., Arafath, S.M., Balakrishnaiah, G., Reddy, R.O.K., Reddy, S.K.N., Lingaswamy, A.P., Kumari, P.S., Devi, U.K., Reddy, R.R. and Babu, S.S. (2015). Columnar-integrated aerosol optical properties and classification of different aerosol types over the semiarid region, Anantapur, Andhra Pradesh. Sci. Total Environ. 527-528: 507-519.

Grivas, G., Cheristanidis, S., Chaloulakou, A., Koutrakis, P. and Mihalopoulos, N. (2018). Elemental composition and source apportionment of fine and coarse particles at traffic and urban background locations in Athens, Greece. Aerosol Air Qual. Res. 18: 1642-1659.

Gupta, S.K. and Elumalai, S.P. (2019). Exposure to trafficrelated particulate matter and deposition dose to auto rickshaw driver in Dhanbad, India. Atmos. Pollut. Res., in Press, doi: 10.1016/j.apr.2019.01.018.

Hao, Y., Gao, C., Deng, S., Yuan, M., Song, W., Lu, Z. and Qiu, Z. (2019). Chemical characterisation of $\mathrm{PM}_{2.5}$ emitted from motor vehicles powered by diesel, gasoline, natural gas and methanol fuel. Sci. Total Environ. 674: 128-139.

Huang, D., Hua, X., Xiu, G.L., Zheng, Y.J., Yu, X.Y. and Long, Y.T. (2017). Secondary ion mass spectrometry: The application in the analysis of atmospheric particulate matter. Anal. Chim. Acta 989: 1-14.

Jiang, N., Guo, Y., Wang, Q., Kang, P., Zhang, R. and Tang, X. (2017). Chemical composition characteristics of $\mathrm{PM}_{2.5}$ in three cities in Henan, central China. Aerosol Air Qual. Res. 17: 2367-2380.

Jin, T., Lu, K., Liu, S., Zhao, S., Qu, L. and Xu, X. (2017). Chemical characteristics of particulate matter emission from a heavy-duty diesel engine using ETC cycle dynamometer test. Aerosol Air Qual. Res. 17: 406-411.

Kerbachi, R., Chikhi, S. and Boughedaoui, M. (2017). Development of real exhaust emission from passenger cars in Algeria by using on-board measurement. Energy Procedia 136: 388-393.

Kim, H.S., Huh, J.B., Hopke, P.K., Holsen, T.M. and Yi, S.M. (2007). Characteristics of the major chemical constituents of $\mathrm{PM}_{2.5}$ and smog events in Seoul, Korea in 2003 and 2004. Atmos. Environ. 41: 6762-6770.

Lin, Y.C., Li, Y.C., Amesho, K.T.T., Chou, F.C. and Cheng, P.C. (2019). Characterization and quantification of $\mathrm{PM}_{2.5}$ emissions and PAHs concentration in $\mathrm{PM}_{2.5}$ from the exhausts of diesel vehicles with various accumulated mileages. Sci. Total Environ. 660: 188-198.

Lipfert, F.W. (2017). Long-term associations of morbidity with air pollution: A catalogue and synthesis. J. Air Waste Manage. Assoc. 68: 12-28.

Liu, Y., Martinet, S., Louis, C., Pasquier, A., Tassel, P. and Perret, P. (2017). Emission characterization of in-use diesel and gasoline Euro 4 to Euro 6 passenger cars tested on chassis dynamometer bench and emission model assessment. Aerosol Air Qual. Res. 17: 2289-2299.

Maricq, M.M., Chase, R.E., Xu, N. and Laing, P. (2002). The effects of the catalytic converter and fuel sulfur level on motor vehicle particulate matter emissions: Gasoline vehicles. Environ. Sci. Technol. 36: 283-289.

May, A.A., Nguyen, N.T., Presto, A.A., Gordon, T.D., Lipsky, E.M., Karve, M., Gutierrez, A., Robertson, W.H., Zhang, M., Brandow, C., Chang, O., Chen, S., Cicero-Fernandez, P., Dinkins, L., Fuentes, M., Huang, S.M., Ling, R., Long, J., Maddox, C., Massetti, J., McCauley, E., Miguel, A., Na, K., Ong, R., Pang, Y., Rieger, P., Sax, T., Truong, T., Vo, T., Chattopadhyay, S., Maldonado, H., Maricq, M.M. and Robinson, A.L. (2014). Gas- and particle-phase primary emissions from in-use, on-road gasoline and diesel vehicles. Atmos. Environ. 88: 247-260.

Ntziachristos, L. and Samaras, Z. (2000). Speed-dependent representative emission factors for catalyst passenger cars and influencing parameters. Atmos. Environ. 34: 4611-4619.

Oanh, N.T.K, Thiansathit, W., Bond, T.C., Subramanian, R., Winijkul, E. and Paw-armart, I. (2010). Compositional characterization of $\mathrm{PM}_{2.5}$ emitted from in-use diesel vehicles. Atmos. Environ. 44: 15-22.

Pervez, S., Bano, S., Watson, J.G., Chow, J.C., Matawle, J.L., Shrivastava, A., Tiwari, S. and Pervez, Y.F. (2018). Source profiles for $\mathrm{PM}_{10-2.5}$ resuspended dust and vehicle exhaust emissions in Central India. Aerosol Air Qual. Res. 18: 1660-1672.

Schauer, J.J., Kleeman, M.J., Cass, G.R. and Simoneit, B.R.T. (1999). Measurement of emissions from air pollution sources. 2. $\mathrm{C}_{1}$ through $\mathrm{C}_{30}$ organic compounds from medium duty diesel trucks. Environ. Sci. Technol. 33: $1578-1587$.

Schauer, J.J. (2003). Evaluation of elemental carbon as a marker for diesel particulate matter. J. Exposure Sci. Environ. Epidemiol. 13: 443-453.

Schmitz, T., Hassel, D. and Weber, F.J. (2000). Determination of VOC-components in the exhaust of gasoline and diesel passenger cars. Atmos. Environ. 34: 4639-4647.

Sen, I.S., Bizimis, M., Tripathi, S.N. and Paul, D. (2016). Lead isotopic fingerprinting of aerosols to characterize the sources of atmospheric lead in an industrial city of India. Atmos. Environ. 129: 27-33.

Sha, Q., Lu, M., Huang, Z., Yuan, Z., Jia, G., Xiao, X., Wu, Y., Zhang, Z., Li, C., Zhong, Z. and Zheng, J. (2019). Anthropogenic atmospheric toxic metals emission inventory and its spatial characteristics in Guangdong province, China. Sci. Total Environ. 670: 1146-1158.

Shen, J. and Gao, Z. (2019). Commuter exposure to particulate matters in four common transportation modes in Nanjing. Build. Environ. 156: 156-170.

Sonnatag, D.B., Baldauf, R.W., Yanca, C.A. and Fulper, C.R. (2014). Particulate matter speciation profiles for light-duty gasoline vehicles in the United States. J. Air Waste Manage. Assoc. 64: 529-545.

Taiwan EPA (2017). Taiwan emission data system (TEDS) 
9.0. Environmental Protection Administration, Taiwan.

UN (2018). World Urbanization Prospects: The 2018 Revision. United Nations, Department of Economic and Social Affairs, Population Division. United Nations.

U.S. EPA (2007). SPECIATE Version 4.2. United States Environmental Protection Agency. https://www.epa.go v/air-emissions-modeling/speciate. Last Access: 17 May, 2019.

Vogt, R., Scheer, V., Casati, R. and Benter, T. (2003). Onroad measurement of particle emission in the exhaust plume of a diesel passenger car. Environ. Sci. Technol. 37: 4070-4076.

Wang, L.C., Lee, W.J., Lee, W.S. and Chang-Chien, G.P. (2010). Emission estimation and congener-specific characterization of polybrominated diphenyl ethers from various stationary and mobile sources. Environ. Pollut. 158: 3108-3115.

Wang, Y., Yue, S., Zheng, B., Hao, Z. and Chen, J. (2018). A general method for evaluating the effects of air pollutants on lung cancer prevalence. J. Air Waste Manage. Assoc. 68: 1366-1377.

Wang, Y.F., Huang, K.L., Lic, C.T., Mi, H.H., Luo, J.H. and Tsai, P.J. (2003). Emissions of fuel metals content from a diesel vehicle engine. Atmos. Environ. 37: 46374643.

WHO (2006). Air quality guidelines global update 2005. World Health Organization, Europe.

Wu, B., Shen, X., Cao, X., Yao, Z. and Wu, Y. (2016). Characterization of the chemical composition of $\mathrm{PM}_{2.5}$ emitted from on-road China III and China IV diesel trucks in Beijing, China. Sci. Total Environ. 551-552: 579-589.

Wu, D., Zhang, F., Lou, W., Li, D. and Chen, J. (2017). Chemical characterization and toxicity assessment of fine particulate matters emitted from the combustion of petrol and diesel fuels. Sci. Total Environ. 605-606: 172-179.

Yang, H.H., Chen, H.W., Chen, C.B. and Chien, S.M. (2005). Effect of fuel properties on particulate matter and polycyclic aromatic hydrocarbon emission from diesel engine in Taiwan. Int. J. App. Sci. Eng. Technol. 3: 27-36.

Yang, H.H., Chien, S.M., Cheng, M.T. and Peng, C.Y. (2007). Comparative study of regulated and unregulated air pollutant emissions before and after conversion of automobiles from gasoline power to liquefied petroleum gas/gasoline dual-fuel retrofits. Environ. Sci. Technol. 41: 8471-8476.

Yang, H.H., Arafath, S.M., Wang, Y.F., Wu, J.Y., Lee, K.T. and Hsieh, Y.S. (2018). Comparison of coal- and oil-fired boilers through the investigation of filterable and condensable $\mathrm{PM}_{2.5}$ sample analysis. Energy Fuels 32: 2993-3002.

Yang, T.T., Hsu, C.Y., Chen, Y.C., Young, L.H., Huang, C.H. and $\mathrm{Ku}, \mathrm{C.H}$. (2017). Characteristics, sources, and health risks of atmospheric $\mathrm{PM}_{2.5}$ bound polycyclic aromatic hydrocarbons in Hsinchu, Taiwan. Aerosol Air Qual. Res. 17: 563-573.

Zhang, J., Wu, L., Fang, X., Li, F., Yang, Z., Wang, T., Mao, H. and Wei, E. (2018). Elemental composition and health risk assessment of $\mathrm{PM}_{10}$ and $\mathrm{PM}_{2.5}$ in the roadside microenvironment in Tianjin, China. Aerosol Air Qual. Res. 18: 1817-1827.

Received for review, April 9, 2019 Revised, May 20, 2019 Accepted, May 25, 2019 